\title{
A Study to Overcome the Problem of Organizational Productivity with Yogic Interventions
}

\author{
Neeru Devi, Independent Researcher, M.Phil, M.Com (UGC-NET). neerukhatricommerce@gmail.com
}

Sheetal, Independent Researcher, M.A. in Yoga (UGC-NET). sheetalkhatri1995@gmail.com

\section{ABSTRACT}

Background - Organizational productivity is a huge problem faced by employer in corporate sector. Many employees do not perform their work effectively and efficiency is also missing in their performance. Yoga has been emerging as an efficient tool to boost positive energy among human beings. It has also been used in corporate sector as a problem solving technique. Various enterprises have used this cost-effective technique to solve the problems such as mental health, wellbeing and stress management and found that yoga brings significant results at workplace.

Purpose - Corporate sector employees work for long hours every day at their respective workplace. This workload leads lack of interest \& the level of productivity diminishes day by day. Yoga practices are helpful in this context as yoga not only helps physically but also relax the mind. This paper is an attempt to find out the effectiveness of Yoga in increasing organizational productivity in corporate sector employees.

Methodology - A review of literature from Indian and international authors were examined to identify the effects of yoga asanas, breathing techniques, meditation and theoretical sessions of yoga on organizational productivity.

Findings - It was found after analyzing literature that Yoga has a significant positive relationship with organizational productivity. Yoga practices, meditation and theoretical sessions of yoga helps corporate sector employees to increase their productivity at individual as well as organizational level.

Practical Implications - This paper recommend that yoga sessions should be organized in each organization at some fixed intervals because it has some empirical evidences like cost effectiveness, stress remover, improved performance and increased productivity in employees. Moreover, it is suggested that these sessions must be hosted by well experienced yoga instructors to remove any inconvenience.

Key Words: Workplace, Yoga Interventions, Organizational Productivity.

\section{INTRODUCTION}

Productivity affects our lives in different manners such as national level, industry or firm level and individual level. Increased productivity tends to produce same product at less inputs. Productivity is important at individual level as well as organizational level to become more effective. An organization can achieve a higher position than its competitors if it has higher productivity than other firms in the same industry. Organizational productivity means both the efficiency and effectiveness in business concern (Pritchard, 1990). Effectiveness here means to complete the task at right time and efficiency refers to do the right task. In 2016, Associated Chambers of Commerce and Industry of India (ASSOCHAM) conducted a survey and found that yoga sessions are being organized at workplace by various organizations to boost the productivity at workplace. It was found that more than $53 \%$ companies were organizing these yoga practices to enhance productivity in their employees.
Yogic processes i.e. Asanas, Pranayama \& Meditation give many health benefits to people (Sheetal, 2020). Yoga is a tool for self-management through which self realization can be done. But yoga alone is not effective in productivity; it works with gender jointly (Choudhary, Dubey, \& Baghel, 2018). Spirituality at workplace leaves a favorable effect on wellness and productivity among employees (VyasDoorgapersad, 2017). Yoga is an ancient practice. It is used for various health benefits worldwide (Sheetal, 2020). Yoga interventions are significantly effective to manage stress and also helpful to improve performance at workplace (Bhandar, Balkrishna, \& Katiyar, 2010). Employees have to use technology at workplace. Use of technology such as smartphone leads to various health problems such as stress, depression and anxiety (Malik \& Devi, 2018). This automatically creates problem in productivity. One of the major problems in organizations is counterproductive work behavior. Yoga not only helps in reducing this 
counterproductive behavior but also improves health of employees through reduction in negativity and aggression. It helps employers to increase productivity among employees (Dwivedi, Kumari, \& Nagendra, 2015).

\section{ObJECTIVE OF THE STUDY}

By considering the problem of employers about organizational productivity, this paper makes an attempt to focus on effectiveness of yogic intervention on productivity. The results would be helpful in further empirical studies and for organizations to solve the problem of counterproductive behavior of employees. This paper is based on extensive literature to identify the impact of yoga in corporate sector with special reference to productivity.

\section{DEVELOPMENTS IN CONCEPTUAL FRAMEWORK}

There is vast literature available on corporate yoga i.e., how yoga effect corporate world. The relationship between yoga and productivity in employees has been explained in literature with different outcomes. Empirical evidence from available literature is collected and an overview has been created in this paper to clear the picture of how yoga affects productivity in organization. Various attributes were identified on the basis of literature regarding types of yoga practices used to enhance productivity:

\subsection{Yoga Asanas and Organizational Productivity}

These are also named as body postures. An integrated practice of yoga asanas increases productivity at workplace (Chokkalingam, Kumari, S., Akhilesh, K.B., \& Nagendra H. R. 2015), (Adhia, H., Nagendra, H. R., \& Mahadevan, B. (2010). A practice of short duration of postures (20 minutes) is also effective to improve emotional well-being at workplace (Hartfiel, N., Havenhand, J., Khalsa, S.B., Clarke, G., \& Krayer, A. 2010). Yoga asans are effective way to enhance work performance in corporate sector (Bhandari, R., Balkrishna, A., \& Katiyar, V. K. 2010). After practicing yoga, employees became helpful to employer in achieving goals (Priyal, V.V. \& Ramkumar, N. 2017). Regular practice of yoga asanas reduce counterproductive work behavior among working professionals (Dwivedi, U. C., Kumari, S., \& Nagendra, H. R. 2016). Gothe, N., Pontifex, M. B., Hillman, C., \& McAuley, E. (2013) added various yoga asanas such as Uttanasan, Vrikshasana, Trikonasana, Parivrtta Trikonasana, Adho Mukha Shvanasana, Ustrasana and Shashankasana in their study to improve executive control and working memory of employees. Dwivedi, U. C., Kumari, S., Akhilesh, K. B., \& Nagendra, H. R. (2015) also added to literature that yoga asanas are cost-effective tools for organizations to improve happiness and productivity in employees. There is a positive impact of yoga practices on employee productivity (Choudhary, R., Dubey, A., \& Baghel, D. 2018).

\subsection{Pranayamas and Organizational Productivity}

These are breathing techniques which are practiced with yoga asanas. Pranayma is an empirical tool to improve work performance (Adhia, H., Nagendra, H. R., \& Mahadevan, B. 2010). Again, Chokkalingam, Kumari, S., Akhilesh, K.B., \& Nagendra H. R. (2015) found that pranayama helps to enhance performance of employees at workplace. Bhandari, R., Balkrishna, A., \& Katiyar, V. K. (2010) provided empirical evidences that pranayams are helpful to improve work performance in corporate world. Dwivedi, U. C., Kumari, S., \& Nagendra, H. R. (2016) indicated in their study that pranayamas with yoga practices are helpful to decreases unproductive behavior in working professionals. Pranayama is supportive in excecutive control and working memory (Gothe, N., Pontifex, M. B., Hillman, C., \& McAuley, E. 2013). Pranayamas are effective technique for organization in improving productivity with minimum cost ( Dwivedi, U. C., Kumari, S., Akhilesh, K. B., \& Nagendra, H. R. 2015).

\subsection{Meditation and Organizational Productivity}

Meditation refers to focus or concentrate mind at one place. It helps to enhance self awareness and increase in performance (Chokkalingam, Kumari, S., Akhilesh, K.B., \& Nagendra H. R. 2015). Meditation helps business in many ways such as clarity, focus, improved loyalty of employees, enhances communication, low rate of absenteeism and also helpful to increase productivity (Mishra, R. K. 2010). Deshpande, R. C. (2012) also evidenced that meditation is a great tool to deal with work stressors. Meditation was practiced by participants and positive results were seen in work performance (Bhandari, R., Balkrishna, A., \& Katiyar, V. K. 2010). Dwivedi, U. C., Kumari, S., \& Nagendra, H. R. (2016) again stated that meditation is helping hand with yoga intervention to increase productive behavior. Meditation is cost-effective way to prevent organizations in losses which arises due to counterproductive behavior (Dwivedi, U. C., Kumari, S., Akhilesh, K. B., \& Nagendra, H. R. 2015).

\subsection{Surya Namaskara and Organizational Productivity}

It is also known as salute to sun or sun salutation. Although surya namaskara is included in the section yogic asanas but some authors specified it as a different aspect. A practice of approximately four months for one and half hours a day increased productivity among employees (Chokkalingam, Kumari, S., .Akhilesh, K.B., \& Nagendra H. R. 2015). Gothe, N., Pontifex, M. B., Hillman, C., \& McAuley, E. (2013) added four minutes sun salutation in their study to executive control, improvements in inhibition and working memory. It has been concluded on the basis of above studies that although surya namaskara is included in overall yogic interventions but it has another level of effectiveness as it is treated as full body exercise. 


\subsection{Theory Sessions on yoga and Organizational Productivity}

Various studies found that a lecture along with yoga practice helps participants to understand the importance of yoga. Adhia, H., Nagendra, H. R., \& Mahadevan, B. (2010) applied 25 hours theory lectures in their study to give knowledge of yogic philosophies to participants from corporate world with practice of other yogic interventions. Chokkalingam, Kumari, S., Akhilesh, K.B., \& Nagendra H. R. (2015) again indicated in their study that a ten minute lecture along with yoga pratice is valuable for employees to improve their performance as they were taught to apply the traditional knowledge in modern problems and lives. Dwivedi, U. C., Kumari, S., \& Nagendra, H. R. (2016) added to literature that theory sessions of yoga literature along with practice are helpful to make understand working professionals about productive behavior. Dwivedi, U. C., Kumari, S., Akhilesh, K. B., \& Nagendra, H. R. (2015) also included theory lectures of yoga in their session along with asanas to improve productivity in employees.

\subsection{Time frame of Yogic Interventions and Organizational Productivity}

Chokkalingam, Kumari, S., .Akhilesh, K.B., \& Nagendra H. R. (2015) investigated effect of yoga on productivity within a time frame of 4 months for 1:30 hours per day and found favorable results. Hartfiel, N., Havenhand, J., Khalsa, S.B., Clarke, G., \& Krayer, A. (2010) conducted a study for six weeks and 1 hour per day dru yoga practice was done to find out the favorable results and concluded that even a short period of yoga is effective to overcome the problems at workplace. Adhia, H., Nagendra, H. R., \& Mahadevan, B. (2010) applied a 6 weeks yoga intervention for 75 minutes per day to find out its effect on happiness and work performance among employees. Dwivedi, U. C., Kumari, S., \& Nagendra, H. R. (2016) added 10 weeks for practicing yoga for 5 days in a week and 1 hour session each day and found significant result of reducing counterproductive work behavior. Gothe, N., Pontifex, M. B., Hillman, C., \& McAuley, E. (2013) applied 20 minutes yogic interventions in their study for executive control, improvements in inhibition and working memory.

From the above attributes, it is clear that yoga interventions are helpful in increasing organizational productivity. The previously explained research papers were analyzed thoroughly with some more research papers for clearer view of the available literature so that an effective overview can be presented:

Table 1: Overview of Effectiveness of Yogic Interventions on Organizational Productivity (2009-2018)

\begin{tabular}{|c|c|c|c|c|c|}
\hline S. No. & $\begin{array}{l}\text { Authors } \\
\text { (Year) }\end{array}$ & Country & $\begin{array}{c}\text { Sample } \\
\text { Size }\end{array}$ & $\begin{array}{l}\text { Statistical Tests } \\
\text { Used }\end{array}$ & Findings \\
\hline 1. & $\begin{array}{l}\text { Choudhary, R., Dubey, } \\
\text { A., \& Baghel, D. } \\
(2018)\end{array}$ & India & 100 & $\begin{array}{l}\text { Descriptive } \\
\text { Statistics and Two- } \\
\text { way ANOVA }\end{array}$ & $\begin{array}{l}\text { The study revealed that yoga practices put positive } \\
\text { impact on productivity of employees. It was suggested } \\
\text { that organizations should use yoga at work for employees } \\
\text { to improve their health so that productivity can be } \\
\text { increased. }\end{array}$ \\
\hline 2. & $\begin{array}{l}\text { Priyal, V. V. \& } \\
\text { Ramkumar, N. (2017) }\end{array}$ & India & 427 & $\begin{array}{l}\text { Independent t-test, } \\
\text { Pearson's } \\
\text { Coefficient } \quad \text { of } \\
\text { Correlation }\end{array}$ & $\begin{array}{l}\text { It was concluded that spirituality and blue-throat } \\
\text { chkraindividuals had a significant correlation has and } \\
\text { they had positive impact on employees to achieve their } \\
\text { goals as they were practicing yoga. }\end{array}$ \\
\hline 3. & $\begin{array}{l}\text { Vyas-Doorgapersad, S. } \\
\text { (2017) }\end{array}$ & South Africa & - & Review Paper & $\begin{array}{l}\text { It was found that spirituality at workplace enhances } \\
\text { wellness among employees and increases productivity } \\
\text { among employees. It was also examined that spirituality } \\
\text { at workplace impacts male and female in different } \\
\text { manner. }\end{array}$ \\
\hline 4. & $\begin{array}{lrr}\text { Dwivedi, } & \text { U. } & \text { C., } \\
\text { Kumari, } & \text { S., } & \& \\
\text { Nagendra, } & \text { H. } & \text { R. } \\
(2016) & & \end{array}$ & India & 160 & $\begin{array}{l}\text { Paired t-test \& } \\
\text { ANCOVA }\end{array}$ & $\begin{array}{l}\text { It was concluded that yoga sessions are reliable and cost } \\
\text { effective and helpful in reducing counter-productive } \\
\text { behavior among employees. Various benefits can be } \\
\text { grabbed which are helpful to improve productivity } \\
\text { without investing much money such as mental and } \\
\text { physical health of employees. }\end{array}$ \\
\hline 5. & $\begin{array}{l}\text { Gothe, N., Keswani, } \\
\text { R., \& McAuley, E. } \\
(2016)\end{array}$ & United States & 118 & Regression Analysis & $\begin{array}{l}\text { Participants who practiced yoga were identified with } \\
\text { improvement in executive functions and cartisol response } \\
\text { by reducing stress level as compare to those who were } \\
\text { doing stretching. }\end{array}$ \\
\hline 6. & $\begin{array}{l}\text { Chokkalingam, } \\
\text { Kumari, S., .Akhilesh, } \\
\text { K.B., \& Nagendra H. } \\
\text { R. (2015) }\end{array}$ & India & 102 & $\begin{array}{lr}\text { Mean, } & \text { Standard } \\
\text { Deviation } & \text { and } \\
\text { ANOVA } & \end{array}$ & $\begin{array}{l}\text { It was found that conscientiousness was increased in } \\
\text { employees after practicing yoga for four months. } \\
\text { Moreover, the integrated yoga practices improved the } \\
\text { performance of among employees. }\end{array}$ \\
\hline 7. & $\begin{array}{l}\text { Dwivedi, U. C., } \\
\text { Kumari, S., Akhilesh, } \\
\text { K. B., \& Nagendra, H. } \\
\text { R. (2015) }\end{array}$ & India & 160 & t-test & $\begin{array}{l}\text { It was identified that participants of yogic practices were } \\
\text { able to reduce aggression and counterproductive behavior } \\
\text { as compared to control group. These yoga practices also } \\
\text { helped them in increasing productivity at workplace. }\end{array}$ \\
\hline
\end{tabular}




\begin{tabular}{|c|c|c|c|c|c|}
\hline 8. & $\begin{array}{lrr}\text { Dwivedi, } & \text { U. } & \text { C., } \\
\text { Kumari, } & \text { S., } & \& \\
\text { Nagendra, } & \text { H. } & \text { R. } \\
(2015) & & \\
\end{array}$ & India & - & Review Paper & $\begin{array}{l}\text { Finding of the study says that yoga practices are helpful } \\
\text { to reduce counterproductive behavior in individuals and } \\
\text { as well as organization as a whole. It also improves life } \\
\text { and interpersonal issues among employees. }\end{array}$ \\
\hline 9. & Vij, R. (2014) & India & 100 & Factor Analysis & $\begin{array}{l}\text { The study found suggestive measures to reduce stress } \\
\text { among teachers and yoga was suggested as a buster } \\
\text { technique to improve their stress level. }\end{array}$ \\
\hline 10. & $\begin{array}{l}\text { Gothe, N., Pontifex, } \\
\text { M. B., Hillman, C., \& } \\
\text { McAuley, E. (2013) }\end{array}$ & United States & 30 & $\begin{array}{l}\text { Repeated-Measures } \\
\text { ANOVA }\end{array}$ & $\begin{array}{l}\text { It was identified that yoga was superior as compare to } \\
\text { aerobics and baseline performance. After yoga results } \\
\text { were sown as increase accuracy and shorter reaction i.e., } \\
\text { cognitive performance was improved. }\end{array}$ \\
\hline 11. & $\begin{array}{l}\text { Adhia, H., Nagendra, } \\
\text { H. R., \& Mahadevan, } \\
\text { B. (2010) }\end{array}$ & India & 60 & $\begin{array}{lr}\text { Independent } & \text { t-test } \\
\text { (paired) } & \text { and } \\
\text { Pearson's } & \\
\text { Correlation } & \\
\text { Coefficient } & \\
\end{array}$ & $\begin{array}{l}\text { It was found that yoga practices had a positive impact on } \\
\text { job satisfaction, goal orientation, affective organizational } \\
\text { commitment and organizational citizenship behavior. }\end{array}$ \\
\hline 12. & 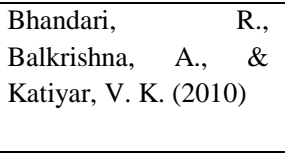 & India & 100 & $\begin{array}{l}\text { Correlation } \\
\text { Coefficient }\end{array}$ & $\begin{array}{l}\text { It was found in this study that yogic interventions play a } \\
\text { favorable role in work performance of employees. It was } \\
\text { also concluded that yoga has a favorable impact on } \\
\text { productivity at individual as well as organizational level. }\end{array}$ \\
\hline 13. & $\begin{array}{l}\text { Hartfiel, N., } \\
\text { Havenhand, J., Khalsa, } \\
\text { S. B., Clarke, G., \& } \\
\text { Krayer, A. (2010) }\end{array}$ & $\begin{array}{c}\text { United } \\
\text { Kingdom }\end{array}$ & 48 & $\begin{array}{l}\text { Descriptive } \\
\text { Statistics }\end{array}$ & $\begin{array}{l}\text { The finding indicated that after six weeks of yoga } \\
\text { practices the employees enhanced emotional well being. } \\
\text { It was suggested to include yoga classes at workplace. }\end{array}$ \\
\hline 14. & Mishra, R. K. (2010) & India & & Review Paper & $\begin{array}{l}\text { It was concluded that yoga and meditation improves } \\
\text { productivity at individual level among employees. And } \\
\text { when it improves at individual level, then overall } \\
\text { productivity of the organization also increases. }\end{array}$ \\
\hline 15. & Hall, T. M. (2009) & United States & 12 & Qualitative Data & $\begin{array}{l}\text { It found examined } \mathrm{b} \text { interviewing twelve participants who } \\
\text { were practicing yoga for more than two years that yoga } \\
\text { increased their productivity and reduced stress level. }\end{array}$ \\
\hline
\end{tabular}

The above table is based on available literature from 20092018 by Indian as well as International authors. This table has examined all the important factors included in the studies such as sample size, country, statistical and empirical results of the study. It represents an overall view of impact of yogic intervention to improve organizational productivity.

\section{CONCLUSION}

Choudhary (2018) supported that as compare to non-yoga practitioners, the yoga practitioners were able to increase their productivity. Chokkalingam, Kumari, Akhilesh, \& Nagendra (2015) also agreed that yoga interventions help to improve conscientiousness and performance of employees at workplace. Vyas-Doorgapersad (2017) again agreed to the fact spirituality at workplace improve wellness and productivity among male and female employees. Gothe, Pontifex, Hillman, \& McAuley (2013) found that yoga brings a positive impact on cognitive assessment and improves task performance of employees. Yoga practices at workplace are cost-effective tool which decreases counterproductive behavior (Dwivedi, Kumari, \& Nagendra, 2015). Bhandari, Balkrishna, \& Katiyar (2010) examined a study on Indian Telephone Industry at Raebrali and found that corporate yoga helps to boost motivation, health, morale and productivity in employees at personal as well as organizational level. All these studies support the positive relationship between organizational productivity and yoga interventions. Hence, yoga is a cost-effective tool which can be used by organization to overcome the problem of productivity. It is suggested to corporate sector that they should organize various yoga sessions to improve productivity of employees at individual as well as organizational level so that both can be benefitted. Yoga is an eminent source which can be used for various health aspects in upcoming studies. 
Humor. International Journal of Environmental Sciences, 2(4), 2143-2154.

[6] Dwivedi, U. C., Kumari, S., \& Nagendra, H. R. (2016). Yoga and its impact on counterproductive work behavior. Medical Journal of Dr. DY Patil University, 9(1), 55-60.

[7] Dwivedi, U., Kumari, S., Akhilesh, K. B., \& Nagendra, H. R. (2015). Effect of Yoga practices in reducing aggression and counterproductive work behavior: A randomized controlled trial. Prabandhan: Indian Journal of Management, 8(10), 21-31.

[8] Dwivedi, U. C., Kumari, S., \& Nagendra, H. R. (2015). Model of yoga intervention in industrial organizational psychology for counterproductive work behavior. Industrial Psychiatry Journal, 24(2), 119124.

[9] Gothe, N. P., Keswani, R. K., \& McAuley, E. (2016). Yoga practice improves executive function by attenuating stress levels. Biological psychology, 121, 109-116.

[10] Gothe, N. P., Pontifex, M. B., Hillman, C., \& McAuley, E. (2013). The acute effects of yoga on executive function. Journal of Physical Activity and Health, 10(4), 488-495.

[11] Hall, T. M. (2009). The impact of practicing yoga on the organization: a study on stress reduction from the participants' perspectives (Doctoral Thesis). The University of San Francisco. United States.

[12] Hartfiel, N., Havenhand, J., Khalsa, S. B., Clarke, G., \& Krayer, A. (2011). The effectiveness of yoga for the improvement of well-being and resilience to stress in the workplace. Scandinavian Journal of Work, Environment \& Health, 70-76.

[13] Malik, S., \& Devi, N. (2018). Problematic smartphone use: a literature review on health issues. Asia Pacific Journal of Research, 1(LXXXVII), 223-230.

[14] Mishra, R. K. (2010). Effect of yoga on Management and employees. International Research Journal of Commerce Arts and Science, 1(1), 173-178.

[15] Pritchard, R. D. (1990). Measuring and improving organizational productivity: A practical guide. Greenwood Publishing Group.

[16] Priyal, V. V., \& Ramkumar, N. (2016). Effect of aurachakra, yoga and spirituality on an individual's performance in the workplace. Studies on EthnoMedicine, 10(2), 166-177.

[17] Sheetal. (2020). An empirical study on effect of yogic regime on hypothyroidism with special reference to Delhi. International Journal of Multidisciplinary Educational Research, 4(7), 164-171.

[18] Sheetal. (2020). An experimental study on obesity and weight management with special reference to yoga practices. International Journal of Physical Education, Sports and Health, 7(2), 269-272.

[19] Vij, R. (2014). A Study of Workplace Stress and the Stifling Productivity of Teaching Faculty of B-schools of National Capital Region of Delhi. Drishtikon: A Management Journal, 5(2), 85-97.

[20] Vyas-Doorgapersad, S. (2017). Workplace spirituality for improved productivity: a gendered perspective. International Journal of Social Sciences and Humanity Studies, 9(2), 143-156. 